\section{Lettuce Stand Establishment in Response to Soil Amendments and Direct-seeding Treatments}

\author{
Dale N. Seale ${ }^{1}$, Daniel J. Cantliffe ${ }^{2}$, and Peter J. Stoffella ${ }^{3}$ \\ Horticultural Sciences Department, Institute ofFood and Agricultural Sciences, \\ University of Florida, Gainesville, FL 32611
}

Additional index words. Lactuca sativa, seed priming, benzyladenine

\begin{abstract}
Primed, primed + BA, or nontreated lettuce (Lactuca sativa L.) seeds were sown with several soil amendment covers or a sandy soil cover (control) to assess stand establishment in three field experiments. Seeds covered with amendments Growsorb LVM 24/48, Growsorb 6/30, and plug-mix had a higher percent emergence than soilcovered seeds in warm soil. Primed seeds (with or without BA) had a higher percent emergence than nontreated seeds. Emergence was more rapid with plug-mix, LVM 24/48, and LVM 6/30 covers than with the sandy soil control. Primed seeds with or without BA also emerged more rapidly and produced heavier seedling shoots than nontreated seeds. Using primed lettuce seeds combined with specific soil amendments can improve lettuce stand establishment under various field conditions. Chemical name used: 6-benzyladenine (BA).
\end{abstract}

Lettuce was harvested on more than 3000 ha and valued at more than $\$ 29.5$ million in Florida during the 1990-91 production season (Florida Agricultural Statistics Service, 1992). Muck soils in the Everglades accounted for $90 \%$ of the lettuce production. However, as muck soils continue to subside due to oxidation, resulting in less productive "shallow muck soils", the lettuce industry in Florida may have to consider shifting production to sandy soils.

Stand establishment of direct-seeded lettuce on sandy soils is generally poorer than on muck soils. Soil crusting, which can result in reduced emergence (Ellis, 1967); fertilizer leaching from heavy rainfalls; and thermodormancy of lettuce seed can contribute to reduced or erratic stands of lettuce grown on sandy soils.

Priming lettuce seed has been reported to overcome thermodormancy (Cantliffe, 198 1; Cantliffe et al., 1984; Guedes and Cantliffe, 1977, 1980; Guedes et al., 1979). Various soil amendments have improved stand establishment of cabbage (Brassica oleracea L. Capitata Group) (Perkins-Veazie and Cantliffe, 1989; Perkins-Veazie et al., 1991) and tomatoes (Lycopersicon esculentum Mill.) (Odell et al., 1992).

The purpose of this investigation was to evaluate seed priming in combination with various soil amendments to improve stand establishment of lettuce grown on sandy soils.

Received for publication 12 Mar. 1993. Accepted for publication 19 July 1993. Florida Agricultural Experiment Station Journal Series no. R-02927. The cost of publishing this paper was defrayed in part by the payment of page charges. Under postal regulations, this paper therefore must be hereby marked advertisement solely to indicate this fact.

'Former Graduate Student.

${ }^{2}$ Professor and Chairman.

${ }^{3}$ Professor, Agricultural Research and Education Center, P.O. Box 248, Fort Pierce, FL 34954.

\section{Materials and Methods}

General field methods. Experiments were conducted on a Pomona sandy soil (Plummer Series; loamy, siliceous, thermic Ultic Grossarenic Paleoquult) at the Institute of Food and Agricultural Sciences Horticultural Unit, Gainesville, Fla. (Expts. 1 and 3) and on a Waveland fine sandy soil (sandy, siliceous, hyperthermic, orstein Arenic Haplaquods) at Zellwood, Fla. (Expt. 2). Raised beds, $20 \mathrm{~cm}$ high and $61 \mathrm{~m}$ wide, were spaced at $1.2 \mathrm{~m}$ (Expts. 1 and 3) and $1.5 \mathrm{~m}$ (Expt. 2) apart, center to center. Fertilizers were incorporated in the bed and banded on the surface in the center of each bed. Fertilizer rates, sowing
'Measured during 14 days after each sowing date, dates, daily mean maximum and minimum air temperatures, and rainfall for each experiment were recorded (Table 1). Plots were $3 \mathrm{~m}$ long and consisted of two rows per bed $30 \mathrm{~cm}$ apart with hills spaced $30 \mathrm{~cm}$ apart. Five seeds of 'Green Lakes' lettuce were placed in each hill and covered with $30 \mathrm{ml}$ of a soil amendment or sandy soil a a control. Overhead sprinkler irrigation was applied after sowing and subsequently as needed (Expts. 1 and 3). For Expt. 2 , a water wagon was used for irrigation immediately after sowing; thereafter, subsurface irrigation was used.

Seedling emergence was counted daily for 9 (Expt. 1) or 14 days (Expts. 2 and 3). Mean days to emergence (MDE) were calculated (Gerson and Honma, 1978) for each plot. Ten seedlings selected at random from each plot were cut just below the cotyledons $\approx 3$ weeks after sowing. Plant samples were oven-dried at $54 \mathrm{C}$ for a minimum of 3 days, and dry weights were recorded.

Seed treatments and soil amendments. Seeds from the same seed lot of 'Green Lakes' lettuce were either nontreated, primed, or primed with $100 \mathrm{mg} \mathrm{BA} /$ liter (Abbott Labs., North Chicago, Ill.) in the priming solution. Seeds were primed in $1 \%(\mathrm{w} / \mathrm{v}) \mathrm{K}_{3} \mathrm{PO}_{4}(20 \mathrm{ml} /$ $\mathrm{g}$ of seed) aerated solution placed in a dark incubator at $15 \mathrm{C}$ for $20 \mathrm{~h}$. Subsequently, seeds were removed from the solution, rinsed several times with distilled water, vacuum-filtered to remove excess moisture, placed between paper towels to remove surface moisture, and then dried at $5 \mathrm{C}$ and $45 \% \mathrm{RH}$ for 48 $\mathrm{h}$. The primed seed were stored in sealed plastic vials until field-sown.

Soil amendment treatments were Growsorb LVM 24/48 (fine-textured calcined montmotillonite clays fired at high temperature; Mid FloridaMining,Lowell, Fla.), GrowsorbRVM $24 / 28$ (fired at low temperature), and plugmix, apeat-verrniculite potting medium (W.R.

Table 1. Sowing date, fertilizer rates, air temperature, and rainfall for each experiment.

\begin{tabular}{|c|c|c|c|c|c|c|c|c|}
\hline \multirow[b]{3}{*}{ Expt. } & \multirow{3}{*}{$\begin{array}{c}\text { Sowing } \\
\text { date }\end{array}$} & & & & & & \multicolumn{2}{|c|}{ Rainfall $^{2}$} \\
\hline & & \multicolumn{3}{|c|}{ Fertilizer $\left(\mathrm{kg} \cdot \mathrm{ha}^{-1}\right)$} & \multicolumn{2}{|c|}{ Temp $\left({ }^{\circ} \mathrm{C}\right)^{2}$} & \multirow{2}{*}{$\begin{array}{l}\text { Days } \\
\text { (no.) }\end{array}$} & \multirow{2}{*}{$\begin{array}{l}\text { Total } \\
(\mathrm{mm})\end{array}$} \\
\hline & & $\mathrm{N}$ & $\mathrm{P}$ & $\mathrm{K}$ & Max & Min & & \\
\hline 1 & 20 Sept. 1984 & 70 & 28 & 70 & 30.5 & 14.9 & 0 & 0 \\
\hline 2 & 20 Nov. 1984 & 94 & 26 & 89 & 22.7 & 13.2 & 4 & 48 \\
\hline 3 & 15 Mar. 1985 & 66 & 26 & 80 & 24.3 & 8.3 & 1 & 18 \\
\hline
\end{tabular}

Table 2. Effects of seed treatments (ST) and soil amendments (SA) on emergence, mean days to emergence (MDE), and seedling shoot dry weight (Expt. 1).

\begin{tabular}{lccc}
\hline Treatments & $\begin{array}{c}\text { Emergence } \\
(\%)\end{array}$ & $\begin{array}{c}\text { MDE } \\
(\text { days })\end{array}$ & $\begin{array}{r}\text { Shoot dry wt } \\
(\mathrm{mg} / \mathrm{shoot})\end{array}$ \\
\hline SA & 78 & 4.3 & 5.4 \\
$\quad$ Soil & 85 & 4.1 & 6.1 \\
Growsorb LVM 24/48 & 82 & 4.3 & 6.8 \\
Growsorb RVM 24/48 & 61 & 4.5 & 4.7 \\
Plug-mix & 8 & 0.2 & 1.1 \\
LSD & & & 6.0 \\
ST & 73 & 4.3 & 5.1 \\
Nontreated & 75 & 4.3 & 6.2 \\
Primed & 81 & 4.2 & 0.9 \\
Primed + BA & 7 & & NS \\
LSD & NS & NS &
\end{tabular}


Grace, Cambridge, Mass.) in Expts. 1 and 2. Growsorb LVM 24/48, Growsorb LVM 6/30 (coarse-textured), Growsorb RVM 6/30 (finetextured), and plug-mix were soil amendment treatments in Expt. 3. A cover of indigenous sandy field soil was a control in each experiment.

Statistical analyses. A randomized complete-block design with each soil amendmentseed treatment combination replicated four times was used in each experiment. Analysis of variance was conducted for each measured variable. Significant main effect or interaction means were separated by LSD test, at $P<0.05$.

\section{Results and Discussion}

Expt. 1. No significant soil amendment $\mathrm{x}$ seed treatment interactions occurred for any of the measured variables (Table 2). Percent emergence or MDE was not improved by Growsorb or plug-mix soil amendments as compared with the soil cover. Plots with Growsorb RVM 24/48 amendment had heavier seedling shoots than plots with the soil cover (Table 2). Seeds primed with BA had a higher percent emergence than nontreated seeds. Seedling shoot weights and MDE from seeds primed with or without BA were similar to those of seedlings from nontreated seeds.

Expt. 2. Soil amendment $\mathbf{x}$ seed treatment interactions were significant for percent emergence and MDE (Table 3). A higher percent emergence occurred in plots with primed + BA seeds covered with plug-mix $(88 \%)$ than in plots sown with nontreated seeds covered with soil $(73 \%)$. Other soil amendment-seed treatment combinations did not improve percent emergence over that achieved with the soil cover. Emergence was more rapid in each primed seed or primed + BA seed plot with RVM $24 / 48$ or plug-mix covers than with nontreated seeds and soil cover plots. Seedling shoot weights were not improved with any soil amendment as compared with the soil cover. However, seedlings from primed seeds had heavier shoots than seedlings from nontreated seed plots (10.6 vs. $8.9 \mathrm{mg} / \mathrm{shoot}$ dry weight; LSD $0.05=1.0$ ). Shoot weight for primed+ BA seed was intermediate $(9.9 \mathrm{mg} / \mathrm{shoot})$.

Expt. 3. Percent emergence was higher and MDE was lower in plots with LVM 24/48, LVM 6/30, and plug-mix soil amendments than in soil-covered plots (Table 4). Plots with RVM 6/30 soil amendment had lower percent emergence and higher MDE than the soilcovered plots. Primed + BA-seeded plots had greater percent emergence and lower MDE than nontreated seed plots.

A significant soil amendment $x$ seed treatment interaction occurred for seedling shoot dry weight (Table 4). Shoot dry weight of seedlings from seeds primed with or without BA and with any combination of soil amendment was higher than that from nontreated seeds with a soil cover. Each soil amendment plot sown with nontreated or primed seeds, except for RVM 6/30, had seedlings with heavier shoots than the soil-covered plots.

Experiments 1, 2, and 3 were conducted under mean temperature regimes of 23,18 , and $16 \mathrm{C}$, respectively (Table 1 ). Rainfall was absent in Expt. 1 and was sporadic during the other experiments (Table 1). Therefore, water was supplied by various irrigation methods that typically are used in the region. Generally, percent emergence was improved by soil amendment covers in Expt. 3. Perhaps the sometimes hot (Expt. 1) or warm (Expt. 2) field conditions increased soil crusting or the rapid drying of seedbeds (Ellis, 1967; Orzolek, 1982). Subseepage irrigation, used in Expt. 2, does not usually wet the bed surface so that surface wetness was absent, as in Expt. 1. Odell et al. (1992) reported similar inconsistent emergence and MDE improvements with soil amendment covers on direct-seeded tomato grown under high-temperature field conditions. However, during cool field conditions, the use of LVM 24/48, LVM 6/30, and plug-mix covers nearly doubled percent emergence as compared with soil covers (Table 3). Primed + BA-treated seeds had higher percent emergence than nontreated seeds under conditions of Expts. 1 and 3. Cantliffe (1991) reported improved germination at $35 \mathrm{C}$, under laboratory conditions, of 'Green Lakes' and 'South Bay' lettuce seeds primed with $1 \%$ $\mathrm{K}_{3} \mathrm{PO}_{4}$ containing BA ( $100 \mathrm{mg} \cdot$ liter ${ }^{1}$ ) as compared with nontreated or primed seeds without BA. MDE generally was lower with the plugmix cover than with the soil cover. Emergence generally was faster from seeds primed with BA (Expts. 1 and 2) or without BA (Expt. 2), regardless of soil amendment, than from nontreated seeds with a soil cover.

Table 3. Effects of seed treatments (ST) and soil amendments (SA) on emergence (Emerg.), mean days to emergence (MDE), and seedling shoot dry weight (Expt. 2).

\begin{tabular}{|c|c|c|c|c|c|c|c|}
\hline \multirow[b]{3}{*}{ Treatments } & \multicolumn{6}{|c|}{ ST } & \multirow{3}{*}{$\begin{array}{c}\text { Shoot } \\
\text { dry wt } \\
\text { (mg/shoot) }\end{array}$} \\
\hline & \multicolumn{2}{|c|}{ Nontreated } & \multicolumn{2}{|c|}{ Primed } & \multicolumn{2}{|c|}{ Primed + BA } & \\
\hline & $\begin{array}{c}\text { Emerg. }^{2} \\
(\%)\end{array}$ & $\begin{array}{l}\text { MDE } \\
\text { (days) }\end{array}$ & $\begin{array}{l}\text { Emerg. } \\
(\%)\end{array}$ & $\begin{array}{l}\text { MDE } \\
\text { (days) }\end{array}$ & $\begin{array}{c}\text { Emerg. } \\
(\%)\end{array}$ & $\begin{array}{l}\text { MDE } \\
\text { (days) }\end{array}$ & \\
\hline \multicolumn{8}{|l|}{ SA } \\
\hline Soil & 73 & 6.5 & 84 & 5.5 & 80 & 6.2 & 10.1 \\
\hline Growsorb LVM 24/48 & 79 & 7.3 & 84 & 5.9 & 82 & 6.0 & 9.6 \\
\hline Growsorb RVM 24/48 & 43 & 6.2 & 69 & 5.5 & 68 & 5.3 & 8.6 \\
\hline Plug-mix & 83 & 5.8 & 83 & 5.4 & 88 & 5.4 & 10.6 \\
\hline $\mathrm{LSD}_{0.05}$ & & & & & & & 1.1 \\
\hline
\end{tabular}

Table 4. Effects of seed treatments (ST) and soil amendments (SA) on emergence (Emerg.), mean days to emergence (MDE), and seedling shoot dry weights (Expt. 3).

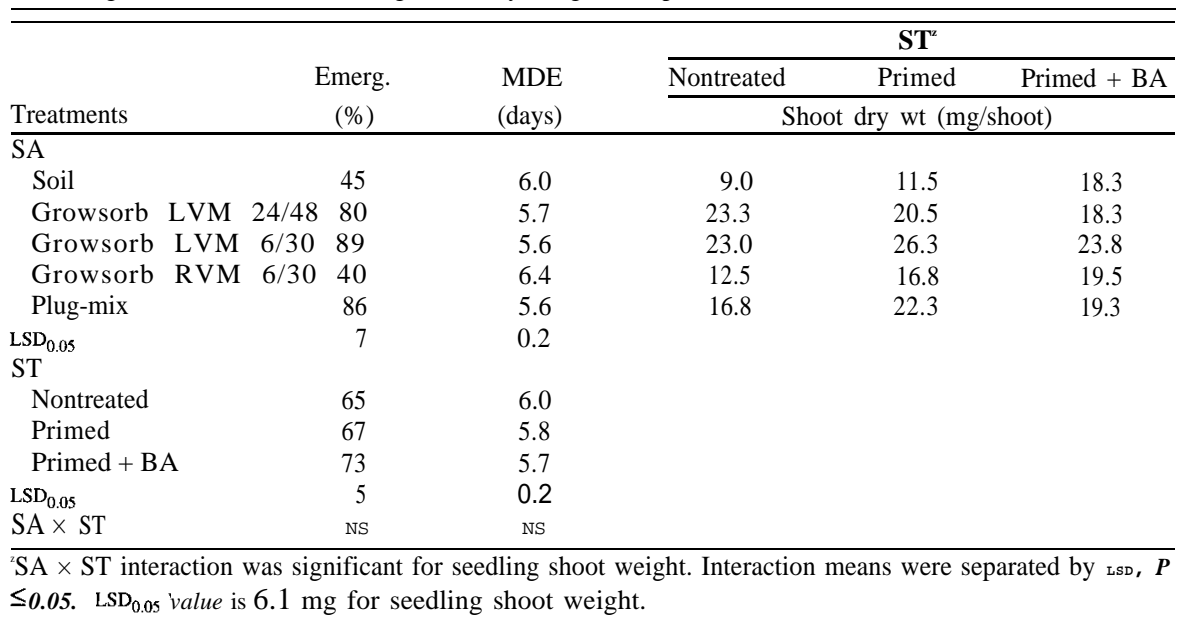

Soil amendments, relative to soil cover, generally increased seedling shoot weight in Expt. 3 (sometimes cool field conditions). However, plots with seeds primed (Expts. 2 and 3) or primed + BA (Expt. 3) resulted in seedlings with heavier shoots than nonprimed eds.

Growsorb compared with the soil cover (Expt. 1). However, there was significant reduced emergence in Expts. 2 and 3, regardless of seed treatment, when this amendment was used. While rain was absent in Expt. 1, three heavy rainfalls occurred directly after seeding in Expt. 2, and one 18-mm rainfall occurred product fired at $288 \mathrm{C}$ absorbs water, while the same product when fired at $611 \mathrm{C}$ becomes the non-water-absorbent LVM product. Heavy ainfall, even for a short period, can lead to water-absorbing properties. The use of plug mix in Expt. 1, when no rainfall occurred during hot weather, had a similar detrimental effect on emergence. Plug-mix can act as a wick under these conditions, leading to rapid ying in and near the mix.

stands of lettuce grown on sandy soils tions were generally improved when seeds were primed with BA. Soil amendments were effective in Expt. 3, in which emergence from soil-covered seeds was severely reduced. Yields under these conditions were directly 
related to total percent emergence (data not shown). Lettuce yields are directly proportional to plant population present and to plant size uniformity. Of the heads harvested in Expt. 3, only 45\% were marketable from the nontreated seed with soil cover plots, while $76 \%$ of the heads from plots with soil amendments were marketable, regardless of seed treatment (data not shown). Optimum lettuce yields could be ensured under hot and dry field conditions through maximizing plant stands regardless of environmental conditions.

\section{Literature Cited}

Cantliffe, D.J. 1981. Seed priming of lettuce for early and uniform emergence under conditions of environmental stress. Acts Hort. 122:29-38.

Cantliffe, D.J. 1991. Benzyladenine in the priming solution reduces thermodormancy of lettuce seeds. HortTechnology 1:95-97.

Cantliffe, D. J., J. M. Fischer, and T. A. Nell, 1984 Mechanism of seed priming in circumventing thermodormancy in lettuce. Plant Physiol. 75:290-294.

Ellis, J.E. 1967. Prevention of stand losses in tomato due to soil crust formation. Proc. Amer. Soc. Hort. Sci. 87:433436.

Florida Agricultural Statistics Service. 1992. Florida Agricultural Statistics. Vegetable summary 1990-1991. Florida Agr. Stat. Serv., Orlando.

Gerson, R. and S. Honma. 1978. Emergence of the pepper at low soil temperature. Euphytica 27:151-156.

Guedes, AC. and D.J. Cantliffe. 1977. Effect of presowing seed treatments on germination of lettuce seed at high temperature. Proc. Fla. State Hort. Soc. 90:418420.

Guedes, A.C. and D.J. Cantliffe. 1980. Germination of lettuce seeds at high temperature after seed priming. J. Amer. Soc. Hort. Sci. 105 :777781.

Guedes, A. C., D.J. Cantliffe, K.D. Shuler, and E. Munter. 1979. Overcoming thermodormancy in lettuce by seed priming. Proc. Fla. State Hort. Soc. 92:130-133.

Odell, G. G., D.J. Cantliffe, H.H. Bryan, and P.J. Stoffella. 1992. Stand establishment of freshmarket tomatoes sown at high temperatures. HortScience 27 :793-795

Orzolek, M.D. 1982. Effects of gels and anticrustants on the emergence and yield of tomatoes. Veg. Res. Rpt. Penn State Univ. p. 54-56.

Perkins-Veazie, P.M. and D.J. Cantliffe. 1989. Improved stand establishment of direct-seeded cabbage with seed covers. J. Amer. Soc. Hort. Sci. 114:3\&39.

Perkins-Veazie, P.M., D.J. Cantliffe, and J.M. White. 1991. Emergence of cabbage seedlings under temperature stress using gels and soil amendments. Scientia Hort. 45: 183-190. 